\title{
Developing a Framework for Emerging Medical Tourism Destinations - An Exploratory study in Lebanon
}

\author{
Samar Noaman ${ }^{1}$, Jean Michel Chapuis ${ }^{2}$ \\ ${ }^{1}$ Assistant Professor, Faculty of Management, Canadian University Dubai, $1^{\text {st }}$ Interchange Sheikh Zayed Road, P.O. Box 117781, \\ Dubai, UAE. \\ ${ }^{2}$ Professor, IREST - Institut de Recherche et d'Etudes Supérieures du Tourisme, University of Paris 1 Panthéon-Sorbonne, 21 , \\ Rue Broca - 75005, Paris, France \\ Corresponding author
}

\begin{abstract}
Several destinations have marked their names on the medical tourism world map while others' potentials are still virtual despite encompassing success factors. This paper structures a framework to understand the supply side of medical tourism and the factors that determine the industry's development. A qualitative approach in the form of semistructured interviews with various stakeholders in the medical tourism field in Lebanon sheds light on the opportunities and challenges to develop such tourism activities in this destination. The content analysis suggests a global fitting of the suggested thematic factors to the data, in terms of costs, infrastructure and superstructure, government attitude, marketing and promotion, expertise/ human resources, language and communication, investment potential, facilities, and attractions. The findings support the role of political stability, interventions of government, and marketing activities. Managerial implications are provided in this research, focusing on enhancing the country's image, encouraging local and foreign investment in the healthcare sector, and promoting fields of specialty, among others.
\end{abstract}

Keywords:- Medical tourism; Middle East; Lebanon; supply analysis.

\section{INTRODUCTION}

$\mathrm{M}_{\mathrm{s}}$ edical tourism is an activity related to mobility with benefits that feed the economy year-round via channels of the tourism sector, healthcare sector and other related sectors. Although there are no exact figures on the global size of the medical tourism market, it is estimated to range between USD 45.5 billion and USD 72 billion and is expected to grow at an annual rate of 15 to $25 \%$ globally ("Patients beyond Borders", 2018). Countries located in the Middle East are expected to be at a crossroad in terms of tourism opportunities between Europe, Africa, and Asia; and hence, represent potential destinations for medical tourism. As in the past centuries, some countries host tourists for medical treatments. The Aqaba and the Dead Sea, the lowest point on earth constitute a cornerstone to health tourism in Jordan (Hornett, 2012). Their development has attracted international visitors through their luxurious hotels, spas, and fitness facilities (Stephano, 2014). Dubai is another hub for medical tourism in the Middle East. With more than 90 medical centers and a number of internationally accredited hospitals, Dubai Healthcare City (DHCC) is a world leading healthcare zone. Nearly two-thirds of its patients coming from outside UAE, DHCC was developed to cater for medical tourists. Surrounding DHCC, exists a range of accommodation options from hotels and hotel apartments (Woodman, 2012).

Known to be a center for medical excellence in the Middle East, Lebanon possesses several success factors that make it a destination for medical tourism, yet its potential as a world-class medical tourism is still virtual. This study is one of the very few that focus on a Middle Eastern destination, particularly Lebanon. Therefore, its findings represent a cornerstone for research work in the field of medical tourism in this region. Moreover, as the academic trend of studying medical tourism has mainly focused on the medical tourists' perception, this study presents the suppliers' perspective which has acquired a smaller share in the medical tourism literature.

Tourism literature provides knowledge about the factors that develop medical tourism. From the medical tourists' perspective, there are various reasons behind the choice of traveling distances, crossing borders and going outside the usual environment in pursuit of medical treatment. Globalization and web-based information are the two main drivers of both tourism and medicine. The internet has created a worldwide podium for patients to access healthcare information and for medical service providers to advertise and promote their services (Lunt et al., 2010). The economic activity of a country directly affects its services costs and prices charged for its community, including healthcare and transportation service sectors (Knowles \& Westcott, 2020). For example, a knee-replacement surgery in India would cost $40 \%$ to $60 \%$ less than the cost in U.S. including all related expenses (Puri et al., 2010). Therefore, middle-income citizens from developed countries choose the offshore healthcare option for the lower prices either because they are price conscious or because their medical procedures are not covered or partially covered by the healthcare insurance such 
as cosmetic surgeries and dental reconstruction (Horowitz et al., 2007). Some patients travel abroad to evade long waiting lists and delays in their home country's medical system where citizens usually await their turn for the medical procedure. This is typical for countries such as Canada and the United Kingdom where the government is a major regulator of the healthcare system (Horowitz et al., 2007). Some patients travel to a destination to undergo a medical procedure that is not available or even restricted in their home countries. China has one of the most unrestricted stem cells policies and regulations compared to many countries (Dhar \& Hsi-en Ho, 2009). Another reason is the anonymity and privacy offered at a foreign destination. Patients can undergo medical procedures such as plastic surgery in private and anonymous surroundings. Moreover, the pleasure of combining medical procedure with leisure and recreation in an exotic location is posed to be a strong driver of medical tourism. In this regard, many countries have developed their medical centers to look like luxurious hotel properties (Han et al., 2015).

This study provides an in-depth vision of the constituents of medical tourism destinations and aspects that conduce to their attractiveness. It explores the framework for understanding the supply of medical tourism in the Middle East, particularly Lebanon. The purpose of this study is to analyze the several factors that drive the development of a destination for medical tourists. Therefore, to know the relative roles and sources of factors contributing to the formation and development of medical tourism destinations.

The research is based on data collected from various stakeholders in the medical tourism field in Lebanon. The paper is structured as follows. Section 1 is an introduction to medical tourism and its development. Section 2 presents a brief overview of several literature streams relevant to the supply of medical tourism. Section 3 introduces the methodology and collection of materials. Section 4 presents an analysis of the findings. Section 5 concludes with managerial recommendations, research limitations and future research avenues (Gössling et al., 2020).

Factors favoring the emergence of medical tourism from the supply side

Medical tourism is defined as "travel with the aim of improving one's health, and also an economic activity that entails trade in services and represents two sectors: medicine and tourism.” (Bookman \& Bookman, 2007, p. 1) Medical tourists are considered as citizens of highly developed nations who bypass services offered in their own communities and travel to less-developed areas of the world for medical care (Horowitz et al., 2007; Knowles \& Westcott, 2020). This study uses a broader approach of organized travel outside someone's healthcare jurisdiction to enhance or restore health through medical intervention (Carrera, 2006).

According to the theory of motivation, the push and pull sides help identify potential factors impacting the tourist's decision-making (Crompton, 1979). Gill and Singh (2011) indicated that competent doctors and high-quality medical treatment facilities, alongside with hotels and food and beverage quality and general tourism supply are factors for deciding whether to embark on a medical trip abroad. According to Alsharif et al. (2010), cost, physician and facility reputation and hospital accreditation were ranked as the most important factors in choosing out-of-country medical care.

Patients beyond Borders (2018) presented various factors that contribute in making a world-class destination for medical tourism. Meanwhile, Heung et al. (2010) found that policies and regulations and government lack of support are barriers to the development of medical tourism. Within the following factors, this current research focuses on exploratory processes in order to substantiate a theoretical model as follows:

Government and private sector investment in healthcare infrastructure: There are some similarities and other differences in the way medical tourism has developed in various countries and the way governments have envisioned and supported this industry. Several destinations have marked their names on the medical tourism world map. Malaysia, a leading destination recognized the importance of the purchasing power of foreign patients since 1998. It is when the Malaysian government established the National Committee for the Promotion of Medical and Health Tourism with the main purpose of attracting medical tourists (Chee, 2007). Similarly, the Indian government paid special attention to medical tourism wherein the emphasis was focused on promoting India as a global health destination. Accordingly, India introduced a medical travel classification of visa, the Mvisa (Chinai \& Goswami, 2007). This is in addition to the various policies and practices all aimed towards enhancing medical tourism in India including promotional strategies for medical tourism, building partnerships with other countries, and hosting more medical exhibitions and conferences (Reddy \& Qadeer, 2010).

Potential for cost savings on medical procedures: Cost has been one of the most explored topics in medical tourism. As it has been considered the main driver behind contemporary medical tourism movement where traveling is directed from developed countries towards developing countries. Several studies have demonstrated the significant dollar savings for performing procedures abroad which could reach up to 90 percent of the cost of the procedure performed at home (Cortez, 2007).

Political transparency and social stability: Several studies in medical tourism discussed this aspect and its relevance in attracting medical tourists. Smith and Forgione (2007) considered political climate one of the three factors affecting the medical tourist's choice of international country location. The proposed supply and demand model of medical tourism by Heung et al. (2010) identified the political condition as a factor for country selection. Another work of 
(Guy et al., 2015, p. 17) considered "favorability of political environment related to terrorism or political uprising" as one the factors that would attract medical tourists when considering the destination country.

Healthcare innovation and achievement: Destinations that marked their names in the medical tourism world map have invested in medical technology. Malaysia, for example, is opting to use advanced medical technology such as telehealth and EHRs. According to the Malaysia Healthcare Travel Council (MHTC), investing in medical technology will elevate Malaysia's healthcare positioning and attract more medical tourists (Bavishi, 2015). It is worth mentioning that the Medical Tourism Index (MTI) listed state-of-the-art medical equipment as an evaluation item in its ranking criteria (Fetscherin \& Stephano, 2015).

Availability of internationally trained and experienced medical staff: Many destinations relied on the expertise of their physicians and medical staff in promoting their medical tourism. For example, expert physicians and hospital staff who have had international training and practice are considered key factor in the growth of medical tourism in India (Mochi et al., 2013). Moreover, MTI considered reputation of doctors an evaluation criterion in its ranking criteria (Fetscherin \& Stephano, 2015).

Sustained reputation for clinical excellence: Several pieces of research in medical tourism stressed the importance of medical reputation which can be classified into destination level and medical provider level. MTI considered the medical reputation at both the country's level and the hospital/facility level determinants for the country's index ranking (Fetscherin $\&$ Stephano, 2015). Ye et al. (2008) proposed a framework of the motivations of medical tourists in which reputation of the destination, hospital and doctors were part of the attracting factors.

Moreover, Heung et al. (2010) as well as Peters and Sauer (2011) considered the experience and reputation of a medical provider an influencing factor for choosing a particular medical provider and destination country.

On a parallel line, demonstrable commitment to international accreditation, quality assurance, and transparency of outcomes is prominent for medical tourism development (Derido, 2021). International accreditation has been sought by many providers and utilized as a means for international competition. It is considered a source of trust for potential consumers who are coming from other countries with different healthcare systems. A common and trusted accreditation in medical tourism is the Joint Commission International (JCI). Countries with JCI accredited healthcare facilities became internationally recognized and trusted medical tourism destinations with international patients traveling to seek healthcare in such accredited healthcare facilities ("International Medical Travel Journal", 2015; "Joint Commission International”, 2018).
Another factor that contributes to the making of a world-class destination for medical tourism is tourism infrastructure. Availability of accommodation, airlines, food and beverage, sightseeing, local transportation, shopping, and entertainment constitute a requirement for lucrative medical tourism destinations (Cormany, 2008).

To explore and analyze the implications, a qualitative study is conducted with medical tourism suppliers in Lebanon.

\section{Medical Tourism Success Factors in Lebanon}

In the footsteps of leading Asian countries, many Middle Eastern destinations succeeded in elevating their medical tourism offers. According to the MTI, Abu Dhabi ranks $5^{\text {th }}$, Jordan $8^{\text {th }}$, Dubai $21^{\text {st }}$, Turkey $29^{\text {th }}$ (Hornett, 2012; Fetscherin \& Stephano, 2015).

Compared to its neighboring countries, Lebanon spends above 6\%, a significant portion of its GDP on healthcare services. This spending rate is one of the highest in the MENA region. Lebanon has 3.5 beds per 1,000 individuals (Bank Bemo, 2013) and has ISO certified hospitals capable of performing specialized medical procedures. The American University of Beirut Medical Center (AUBMC), established in 1902, has a long history as being one of the leading medical centers in the Middle East. AUBMC is a medical center that handles more than 360,000 patient visits a year (AUBMC, 2018). Another state-of-the-art medical center that has earned the JCI Accreditation is Clemenceau Medical Center (CMC). With a one-on-one nurse ratio, $\mathrm{CMC}$ has gained its reputation for being a luxurious and friendly environment where patients enjoy the ambiance of a 5-star hotel ("Clemenceau Medical Center", 2014). However, it is worth mentioning that in Summer 2020 and as a response to the current economic crisis, AUBMC fired, together with American University of Beirut (AUB), nearly half of its staff (Azzi, 2020).

\section{METHODOLOGY}

A qualitative research method in the form of semistructured interviews is used (Berg, 2004; Saunders et al., 2019). It identifies more precisely the variables of interest and is relevant to collect parallel information from a wider variety of representatives in various contexts related to medical tourism. The sampling approach was purposive as respondents were selected based on their roles and experience as suppliers of medical tourism services including managers of medical centers, clinics, travel agencies, and hotels (Hassan \& Noaman, 2017; Saunders et al; 2019). Semi-structured interviews provided the framework and guided the interviewees in their talks while open-ended questions gave space for in-depth information (Berg, 2004; Gill et al., 2008).

\section{Data collection procedure}

A general interview guide approach was adopted to ensure that the same fields of information are collected from each interviewee following Heung et al. (2010) and Patients 
beyond Borders (2018). Over 15 individuals contacted, 12 interviews were conducted as shown in table 1 . The respondents were informed beforehand of the research purpose and details. To validate the accuracy of the interview content, emails were sent to the respondents with a summary of contents. All respondents approved that contents were consistent and coherent with original interview answers. (See Table 1)

Table 1: Profiles of Respondents

\begin{tabular}{|c|c|c|c|}
\hline Respondents & Title/Position & Age & $\begin{array}{c}\text { Length of } \\
\text { interview }\end{array}$ \\
\hline Respondent 1 & $\begin{array}{c}\text { Owner and managing director of } \\
\text { a medical center }\end{array}$ & 40 & 15 minutes \\
\hline Respondent 2 & $\begin{array}{c}\text { Owner and manager of a } \\
\text { pharmacy }\end{array}$ & 56 & 25 minutes \\
\hline Respondent 3 & $\begin{array}{c}\text { Operations manager at a travel } \\
\text { agency }\end{array}$ & 25 & 21 minutes \\
\hline Respondent 4 & Sales director at a travel agency & 31 & 28 minutes \\
\hline Respondent 5 & $\begin{array}{c}\text { Medical doctor at a medical } \\
\text { center }\end{array}$ & 30 & 18 minutes \\
\hline Respondent 6 & $\begin{array}{c}\text { Medical doctor and head of unit } \\
\text { at a hospital }\end{array}$ & 58 & 30 minutes \\
\hline Respondent 7 & $\begin{array}{c}\text { Manager at a medical cosmetic } \\
\text { clinic }\end{array}$ & 29 & 22 minutes \\
\hline Respondent 8 & Front office manager at a hotel & 27 & 20 minutes \\
\hline Respondent 9 & $\begin{array}{c}\text { Medical doctor at a medical } \\
\text { cosmetic clinic }\end{array}$ & 42 & 21 minutes \\
\hline $\begin{array}{c}\text { Respondent } \\
10\end{array}$ & Sales executive at a hotel & 24 & 18 minutes \\
\hline $\begin{array}{c}\text { Respondent } \\
11\end{array}$ & $\begin{array}{c}\text { Marketing and PR } \\
\text { representative at a medical } \\
\text { center }\end{array}$ & 29 & 22 minutes \\
\hline $\begin{array}{c}\text { Respondent } \\
12\end{array}$ & Nurse at a medical center & 41 & 23 minutes \\
\hline
\end{tabular}

Data analysis

Data were analyzed through three stages following methods widely used in management and social sciences research (Berg, 2004). First, the interviews were transcribed from the audio recorder along with the notes taken during the interview in preparation for content analysis. Second, the data were classified into categories obtained by clustering the themes. Further on, the data were compared with previous literature, analyzed, and synthesized.

\section{FINDINGS}

The content analysis was categorized as per the study of Heung et al. (2010) into "government attitude", "Cost", "infrastructure and superstructure", "policies and regulations", "promotion", "Expertise/manpower", "language and communication", "facilities and tourist attractions". An additional category was added that is "political stability and security" since all respondents identified this category as the main barrier to medical tourism development in Lebanon. It was ranked highest among barriers. Equally high was "promotion" as all respondents highlighted that more support is needed from the government. Government attitude was another strong factor, along with a lack of new policies and regulations.

\section{Political stability and security:}

Expected from the tourism literature (Chapuis et al., 2015) and the current state of affairs in Lebanon, political transparency and social stability were classified as the main factor that attributed to making a destination for medical tourism. Political stability and security were mentioned in each conducted interview and described as the main barrier. Some respondents emphasized a rising issue resulting from the unstable situation in Lebanon and other Middle Eastern countries such as Syria and Iraq.

\section{Government attitude:}

Although medical tourism is mainly established through the private sector, yet, the government plays a vital role in its development. All the interviewees stressed out the fact that the government is not playing a role in supporting medical tourism in Lebanon. An interviewee attributed this deficiency to the lack of financial resources since the Lebanese economy has a high debt to GDP ratio.

Furthermore, the Lebanese economy has been facing corruption of the political elite and a fluctuating exchange rate. According to one respondent "It is very challenging for the government to support the medical tourism sector, PrivatePublic Partnerships and reducing taxes on investment since Lebanon is not a rich country and lacks resources at the moment." On the contrary, according to officials in Dubai, the main drivers contributing to Dubai's MT growth are the emirate's regulatory environment, capacity planning and encouragement of Public-Private Partnership (PPP) (D'Souza, 2013).

\section{Policies and regulations:}

One interviewee mentioned that Lebanese law does not allow pharmacies in Lebanon to advertise for them. The Lebanese Order of Physicians does not allow to advertise for physicians, medical doctors, and medical procedures.

\section{Promotion:}

There was a consensus by all respondents on lack of promotion which they expect the government to support. According to one respondent

"The campaigns that the Lebanese government launch is restricted on the tourism sector in general and are not targeted towards niche tourism sectors such as medical tourism. The Lebanese government participates through the Ministry of Tourism in international Conventions and Exhibitions abroad such as ATM Dubai, ITB Berlin, WTM London, and Istanbul Convention. However, in such exhibitions, the promotion is for Lebanese tourism in General and not specific to niche segments."

Some respondents suggested that Lebanon should create an image especially in plastic surgery since it is highly reputable in this field. According to one respondent "Plastic 
surgery is in demand and Lebanon is very well-known for plastic surgery."

\section{Costs:}

Some respondents claimed that costs of medical service in Lebanon are high while others claimed that they are comparable to what the region is offering. One respondent stated

"The cost depends on the tourist country of origin. If the tourists are coming from a country with poor economy, they would find prices of medical services in Lebanon relatively expensive. However, if the tourists are coming from a country with a prosperous economy, they would find the prices reasonable."

Another respondent claimed that the tourist who is coming to Lebanon for medical treatment is primarily targeting the quality and is willing to pay the current prices. Such a segment is not price sensitive yet driven by medical quality.

\section{INFRASTRUCTURE AND SUPERSTRUCTURE}

Almost all respondents claimed that Lebanon has adequate infrastructure and superstructure with potential areas for improvements. Most respondents claimed that the transportation network is one of the major drawbacks in the Lebanese infrastructure. The lack of adequate public transportation systems such as an underground system or a train system results in traffic congestions. According to one respondent "It is not easy for a tourist to reach addresses and destinations inside Beirut. Most medical tourists approaching the clinic will prefer to stay in a nearby hotel to avoid the hassle of transportation." On the other side, Lebanon has a variety of malls, shopping centers, souks, restaurants, night clubs, and other facilities that combine western and local culture and taste. Modern hotels are also built within the same vicinity of medical centers which makes it more convenient for the medical tourists and their traveling companions.

\section{Expertise/manpower:}

Almost all respondents stated that the primary reason for medical tourism in Lebanon is highly qualified physicians. Many Lebanese physicians hold degrees from well-reputable universities in Lebanon that are affiliated with American and French universities ${ }^{i}$. However, Lebanon is a donor country of doctors and physicians with the highest immigration factor in the Middle East and North Africa (Akl et al., 2008). Over the past 25 years, around $40 \%$ of graduating doctors and physicians from Lebanese medical universities are practicing medicine in the USA (Sayegh \& Badr, 2012). Accordingly, the Lebanese doctors are in demand. According to one respondent,

"In the aesthetic field, Lebanese doctors are most famous. The Arab region trusts the capability of the Lebanese cosmetic doctors as being most professional achieving best results."
Another respondent stated

"Most well-known Lebanese doctors and especially in the field of aesthetic have established clinics in the neighboring countries such as the GCC countries and accordingly these famous doctors will go and treat the patient in their home countries instead of having them come to Lebanon as medical tourists. Many Lebanese doctors have certain types of contracts with the GCC countries as well and they travel on a regular basis to such countries. This affects negatively medical tourism in Lebanon."

\section{LANGUAGE AND COMMUNICATION:}

All respondents stressed that there is no language barrier between medical staff and medical tourists since almost all workers in the field of healthcare are highly educated and speak English, French or both in addition to Arabic.

\section{Facilities and tourist attractions:}

Lebanon is a major touristic destination in the region. It has a strategic geographic location that is proximate to many Arab and European countries. It also enjoys a warm climate and a variety of landscapes ranging from the Mediterranean seaside to green mountains and valleys. Travel and Tourism sector provides a significant contribution to the Lebanese economy and constitutes one of the economy's leading growth engines (Bank Med, 2013). An area of development is the prices of food and beverage as two respondents claimed that they received feedback from many medical tourists indicating the high prices of food and beverage which need further reconsideration. However, few respondents related tourism infrastructure to medical tourism in Lebanon.

\section{CONCLUSION, RECOMMENDATIONS, AND FUTURE RESEARCH POTENTIALS}

A qualitative method was done to explore and analyze the determining factors impacting medical tourism. The content analysis suggests a fitting of the thematic clustering to the data, in terms of costs, infrastructure and superstructure, government attitude, marketing and promotion, expertise/ human resources, language and communication, investment potential, facilities and attractions (Heung et al., 2010; Peters \& Sauer, 2011; Yeoh, 2013). Respondents ranked political instability and government lack of support as main inhibitors while tourism infrastructure looks like a must-have for the development of medical tourism in Lebanon (Hassan \& Noaman, 2017; El-Bacha, 2020a; Rogoff, 2020). Moreover, physicians' expertise is a key driver that can be further utilized to enhance medical tourism in Lebanon.

Overall results confirm the findings of Alsharif et al. (2010). For academics, the findings support that tourism factors as well as medical factors must be considered similar to the results of Heung et al. (2010). Recommendations for private and public managers for developing medical tourism in Lebanon follow. This study is of value and benefit to other countries that are aiming to develop the same sector. 
First and foremost, the Lebanese government needs to maintain a sustainable status of political stability and security. Despite the challenge, particularly after the explosion of Beirut Harbor on 2020 August 4, efforts need to be channelized towards addressing a positive and secure image of Lebanon internationally. This stability needs to extend to the economic sector to have a stable exchange rate. Such would be a core requirement for the return of tourists' influx to Lebanon including medical tourists. Moreover, special campaigns promoting fields of specialty such as cosmetic surgery seem to fit efficiently as Lebanon already holds clinics and medical centers to host tourists.

Encouraging local and foreign investment in the health-care sector, by reducing the associated operational risks is likely to boost medical tourism. A constructive step can be achieved by building cooperation between hospitals and travel agencies to create full packages addressed for potential markets abroad.

Some limitations were faced during this study as it was intended to reach a bigger pool of interviewees. The current context within the region is not usual business conditions. The variables of the qualitative method employed in this study can be further developed and tested quantitatively in future studies across countries. A further step is to conduct a comparative supply-demand analysis with respect to factors affecting medical tourists' destination and medical institution choices.

\section{DECLARATION OF INTEREST}

None

\section{ETHICS DECLARATIONS}

Requirement for approval was waived by the ethics committee.

\section{REFERENCES}

[1] Akl, E., Maroun, N., Major, S., Afif, C., Abdo, A., Choucair, J. Sakr, M., Li, C. K., Grant, B., \& Schünemann, H. (2008). Postgraduation migration intentions of students of Lebanese medical schools: a survey study. BMC Public Health, 8(191). doi.org/10.1186/1471-2458-8-191

[2] Alsharif, J., Labonté, R., \& Lu, Z. (2010). Patients beyond borders: A study of medical tourists in four countries. Global Social Policy, 10(3), 315-335.

[3] AUBMC. (2015, April). AUB faculty of medicine ranks first in the Arab world. https://aubmc.org.lb/Pages/AUB-Faculty-ofMedicine-Ranks-First-in-the-Arab-

World.aspx\#: :text=The\%20American\%20University\%20of\%20B eirut,released\%20Wednesday\%20April\%2029th\%2C\%202015.

[4] AUBMC. (2018). AUBMC 2020 Vision. https://aubmc.org.lb/2020/Pages/pvision2020.aspx\#: :text=The\%2 0AUBMC $\% 202020 \% 20$ Vision\%20is\%20transforming\%20medica $1 \% 20$ education $\% 2 \mathrm{C} \% 20$ research $\% 20$ and,to $\% 20$ new $\% 20$ levels $\% 2$ 0of\%20xcellence

[5] Aydin, D., \& Yilmaz, C. (2011). Medical tourism research. Republic of Turkey Ministry of Health General Directorate of Primary Healthcare Services. www.agtanitim.com

[6] Azzi, B. (2020, July 18). AUBMC lays off hundreds of staff members. Beirut Today. https://beirut- today.com/2020/07/18/aubmc-lays-off-hundreds-of-staffmembers/

[7] Bank Bemo (2013, June). Hospitals in Lebanon. The Monthly Bulletin.

http://www.bemobank.com/files/Hospital\%20Industry\%20Report. $\% 20 J u n e \% 202013$.pdf

[8] Bank Med (2013, August). Analysis of Lebanon's Travel and Tourism Sector (2008-2013). https://www.bankmed.com.lb/BOMedia/subservices/categories/Ne ws/20150515165438196.pdf

[9] Barua, B., \& Esmail, N. (2013, December). Seeking relief outside Canada's borders. Frasier Institute. http://www.fraserinstitute.org/researchnews/news/display. aspx?id=20716

[10] Bavishi, A. (2015, September 07). Malaysia and Thailand take on Singapore for high-tech medical crown. Pulse+IT. https://www.pulseitmagazine.com.au/news/asia-pacific-healthit/2648-malaysia-and-thailand-take-on-singapore-for-high-techmedical-crown/

[11] Berg, B. (2004). An Introduction to Content Analysis. Qualitative Research Methods ( $5^{\text {th }}$ Ed.). Pearson.

[12] Bookman, M. Z., \& Bookman, K. R. (2007). Medical Tourism in Developing Countries. Gordonsville, VA: Palgrave Macmillan

[13] Carrera, P. (2006). Medical Tourism. Health Affairs, 25(5), 14511454.

[14] Chapuis, J. M., Le Falher, C., \& Gonzalez, M., (2015). Destination image, perceived risk and intention to visit. A paper submitted to University Paris1 Panthéon-Sorbonne Institute for the Research Higher Studies of Tourism. Paris: University Paris1 Panthéon-Sorbonne [H5]

[15] Chinai, R., \& Goswami, R. (2007). Medical visas mark growth of Indian medical tourism. Bulletin of the World Health Organization, 85(3), 164-165.

[16] Clemenceau Medical Center. (2016). Medical tourism milestone for Lebanon as Clemenceau Medical Center becomes first hospital to receive international certification (05/09/2014). https://www.cmc.com.lb/events_achievements/pages/Medicaltourism-milestone-for-Lebanon-as-Clemenceau-Medical-Centerbecomes-first-hospital-to-receive-international-certification05092014

[17] Cormany, D. (2008, November 07). Taking a pulse on potential medical tourism destinations: the hospitality and tourism industries. Medical Tourism Magazine, 34-37.

[18] Cortez, N. (2008). Patients without borders: The emerging global market for patients and the evolution of modern health care. Indiana Law Journal, 83(1).

[19] Crompton, J. L. (1979). An assessment of the image of Mexico as a vacation destination and the influence of geographical location upon that image. Journal of Travel Research, 17(4), 18-23.

[20] Dhar, D., \& Hsi-En Ho, J. (2009). Stem cell research policies around the world. Yale Journal of Biolology and Medicine, 82(3), 113-115.

[21] D'Souza, C. (2013, February 09). Dubai medical tourism initiative bolstered. Gulf News Health. https://gulfnews.com/uae/health/dubai-medical-tourism-initiativebolstered-1.1143870

[22] El-Bacha, F. (2020, July 27). Coronavirus: L'erreur libanaise. Libnanews. onavirus-lerreur-libanaise/

[23] Fetscherin, M., \& Stephano, R.M. (2016). The Medical Tourism Index: Scale development and validation. Tourism Management, $52,539-556$

[24] Gill, H., \& Singh, N. (2011). Exploring the Factors that Affect the Choice of Destination for Medical Tourism. Journal of Service Science and Management, 4(3), 315-324.

[25] Gill, P., Stewart, K., Treasure, E., \& Chadwick, B. (2008). Methods of data collection in qualitative research: interviews and focus groups. British Dental Journal, 204(6), 291-295.

[26] Gössling, S. Scott, D., \& Michael Hall, C. (2020). Pandemics, tourism and global change: a rapid assessment of COVID-19, Journal of Sustainable Tourism, 28, 1-20. 
[27] Guy, B., Nevins Henson, J., \& Dotson, M. (2015). Characteristics of consumers likely and unlikely to participate in medical tourism. International Journal of Healthcare Management, 8(2), 68-76.

[28] Han, H., Kim, Y., Kim, C., \& Ham, S. (2015). Medical hotels in the growing healthcare business industry: Impact of international travelers' perceived outcomes. Journal of Business Research, 68(9).

[29] Hassan, V. \& Noaman, S. (2017). Relation between tourism and health: Case study AIDS in Lebanon [Conference session] ATINER'S 13th Annual Conference on Tourism, Athens, Greece. Paper Series, No: TOU2017-2262. 3-16. https://www.atiner.gr/papers/TOU2017-2262.pdf

[30] Chee, H. L. (2007). Medical tourism in Malaysia: Imovement of healthcare consumers and the commodification of healthcare. Asia Research Institute of National University of Singapore, 83.

[31] Heung, V. C., Kucukusta, D., \& Song, H. (2010). A conceptual model of medical tourism: Implications for future research. Journal of Travel and Tourism Marketing, 27(3), 236-251.

[32] Hornett, G., (2012). Government shifts tourism strategy: Special Report Jordan, Middle East Economic Digest, 56(45).

[33] Horowitz, M. D., Rosensweig, J. A., \& Jones, C. A. (2007). Medical tourism: Globalization of the healthcare marketplace. Medscape General Medicine, 9(4), 33.

[34] International Medical Travel Journal. (2015, July 10). Jordan seeks to get medical tourism back on track. http://www.imtj.com/news/jordan-seeks-get-medical-tourismback-track/

[35] Joint Commission International. (2018). Who is JCI. https://www.jointcommissioninternational.org/about-jci/who-isjci/

[36] Knowles H., \& Westcott, M. (2020). Chapter 7. Travel Services. In M. Westcott (Ed.), Introduction to Tourism and Hospitality in $B C$. Capilano University.

[37] Lunt, N., Hardey, M., \& Mannion, R. (2010). Nip, tuck and click Medical tourism and the emergence of web-based health information. The Open Medical Informatics Journal, 4(1).

[38] Mochi, P., Shetty, N., \& Vahoniya, D. (2013). Medical tourismdestination India. National Monthly Referred Journal of Research in Commerce \& Management, 2(3), 29-39.
[39] Patients Beyond Borders. (2018). Medical tourism statistics and facts. http://www.patientsbeyondborders.com/medical-tourismstatistics-facts

[40] Peters, C. R., \& Sauer, K. M. (2011). A survey of medical tourism service providers. Journal of Marketing Development and Competitiveness. 5(3), 117-126.

[41] Puri S., Singh A., \& Yashik S. (2010). Medical tourism - A new arena. Iranian Journal of Public Health, 39(3), 16-19. http://www.ncbi.nlm.nih.gov/pmc/articles/PMC3481623/

[42] Reddy, S., \& Qadeer, I. (2010, May 15). Medical tourism in India: Progress or predicament?. Economic \& Political Weekly, 69. http://www.environmentportal.in/files/Medical\%20Tourism\%20in $\%$ 20India.pdf

[43] Rogoff, K. (2020). Mapping the COVID-19 recession. https://www.project-syndicate.org/commentary/mapping-covid19global-recession-worst-in-150-years-by-kenneth-rogoff-2020-04

[44] Saunders, M., Lewis, P., Thornhill, A., \& Bristow, A. (2019). Research Methods for Business Students. ( $8^{\text {th }}$ Edition). Pearson Education.

[45] Sayegh, M., \& Badr, K. (2012). Reversing the brain drain: A Lebanese model. Nature Middle East: Emerging Science in the Arab World, 143. http://www.natureasia.com/en/nmiddleeast/article/10.1038/nmiddl eeast.2012.143

[46] Smith, P. \& Forgione, D. (2007). Global outsourcing of healthcare: A medical tourism decision model. Journal of Information Technology Care and Application Research, 9(3), 1930.

[47] Stephano, R. (2014). Just doing it: Jordan making name for itself in medical tourism. Medical Tourism Magazine. magazine.medicaltourism.com/article/just-making-name-medicaltourism-jordan

[48] Woodman, J., (2012). Patients Beyond Borders: Dubai Healthcare City Edition. Chapel Hill, NC: Healthy Travel Media.

[49] Ye, B. H., Yuen, P. P., Qiu, H. Z., \& Zhang, V. H. (2008). Motivation of medical tourists: An exploratory case study of Hong Kong medical tourists. In A PTA annual conference, Bangkok, Thailand.

[50] Yeoh, E., Othman, K., \& Ahmad, H. (2013). Understanding medical tourists: Word-of-mouth and viral marketing as potent marketing tools. Tourism Management, 34, 196-201. 
International Journal of Research and Scientific Innovation (IJRSI) | Volume VIII, Issue VII, July 2021|ISSN 2321-2705

Table 1: Profiles of Respondents

\begin{tabular}{|l|l|l|l|}
\hline Respondents & Title/Position & Age & Length of interview \\
\hline Respondent 1 & Owner and managing director of a medical center & 40 & 15 minutes \\
\hline Respondent 2 & Owner and manager of a pharmacy & 56 & 25 minutes \\
\hline Respondent 3 & Operations manager at a travel agency & 25 & 21 minutes \\
\hline Respondent 4 & Sales director at a travel agency & 31 & 28 minutes \\
\hline Respondent 5 & Medical doctor at a medical center & 30 & 18 minutes \\
\hline Respondent 6 & Medical doctor and head of unit at a hospital & 58 & 30 minutes \\
\hline Respondent 7 & Manager at a medical cosmetic clinic & 29 & 22 minutes \\
\hline Respondent 8 & Front office manager at a hotel & 27 & 20 minutes \\
\hline Respondent 9 & Medical doctor at a medical cosmetic clinic & 42 & 21 minutes \\
\hline Respondent 10 & Sales executive at a hotel & 24 & 18 minutes \\
\hline Respondent 11 & Marketing and PR representative at a medical center & 29 & 22 minutes \\
\hline Respondent 12 & Nurse at a medical center & 41 & 23 minutes \\
\hline
\end{tabular}

'The American University of Beirut was ranked among the world's elite 300 universities and has the highest-ranking university in the Arab region in the field of medicine according to the 2015 Quacquarelli Symonds (QS) World University Rankings by Subject released Wednesday April 29th, 2015 (AUBMC, 2015). 